\title{
Inhibition of neutrophil respiratory burst and degranulation responses by CVT-E002, the main active ingredient in COLD-FX
}

Renjith Pillai, Paige Lacy ${ }^{*}$

From Canadian Society of Allergy and Clinical Immunology Annual Scientific Meeting 2011

Quebec, Canada. 20-23 October 2011

\section{Background}

Human peripheral blood neutrophils contribute to the first line of defence in the immune system and are critical for maintaining health and immunity against opportunistic infections. Neutrophils and their granule-derived mediators are frequently found elevated in patient samples in viral infections, asthma exacerbations, and other respiratory ailments. COLD-FX has been shown to reduce the symptoms and severity of respiratory tract viral infections. Our hypothesis is that COLD-FX modulates neutrophil activity. To determine the effects of COLD-FX on neutrophils, peripheral blood neutrophils ( $>97 \%$ purity) were isolated from healthy human volunteers.

\section{Methods}

Neutrophils were preincubated with varying doses of CVT-E002 $(0.01-1 \mathrm{mg} / \mathrm{ml})$, the active ingredient of COLD-FX, for 30, 60, and $120 \mathrm{~min}$. Extracellular ROS production was measured by cytochrome c reduction from neutrophils stimulated with $50 \mathrm{ng} / \mathrm{ml}$ phorbol myristate acetate for up to $60 \mathrm{~min}$. Degranulation was measured by the presence of extracellular myeloperoxidase, a marker of the azurophilic granules, in neutrophils stimulated with cytochalasin B and f-Met-Leu-Phe for 15 min.

\section{Results}

CVT-E002 $(1 \mathrm{mg} / \mathrm{ml})$ had no significant effect on viability at up to $120 \mathrm{~min}$ of incubation. At $60 \mathrm{~min}$ of incubation with CVT-E002, neutrophils showed a 30\% reduction in ROS generation $(\mathrm{p}<0.001)$ which was maintained for up to $120 \mathrm{~min}$. Preliminary experiments also showed that

Pulmonary Research Group, Department of Medicine, University of Alberta, Edmonton, AB, Canada T6G 2S2 incubation of neutrophils with CVT-E002 for $30 \mathrm{~min}$ inhibited myeloperoxidase release.

\section{Conclusions}

These novel findings demonstrate that COLD-FX significantly reduces activation of neutrophils. The implications of this study are that COLD-FX may reduce oxidative stress and tissue-damage triggered by neutrophilic inflammation and activation.

Funding source: Afexa Life Sciences, Inc.

Published: 14 November 2011

doi:10.1186/1710-1492-7-S2-A31

Cite this article as: Pillai and Lacy: Inhibition of neutrophil respiratory

burst and degranulation responses by CVT-E002, the main active ingredient in COLD-FX. Allergy, Asthma \& Clinical Immunology 2011 7(Suppl 2):A31.

Submit your next manuscript to BioMed Central and take full advantage of:

- Convenient online submission

- Thorough peer review

- No space constraints or color figure charges

- Immediate publication on acceptance

- Inclusion in PubMed, CAS, Scopus and Google Scholar

- Research which is freely available for redistribution

Submit your manuscript at www.biomedcentral.com/submit
() Biomed Central

\section{Biomed Central}

(c) 2011 Pillai and Lacy; licensee BioMed Central Ltd. This is an open access article distributed under the terms of the Creative Commons Attribution License (http://creativecommons.org/licenses/by/2.0), which permits unrestricted use, distribution, and reproduction in any medium, provided the original work is properly cited. 